\title{
Bakteri Denitrifikasi Inaktif Sebagai Suplemen Untuk Mengurangi Gas Metana dari Cairan Rumen Sapi
}

\section{Inactivated-Denitrifying Bacteria as a Supplement to Reduce Methane Gas from the Cow Rumen Liquid}

\author{
Megga Ratnasari Pikoli ${ }^{1}$, Farah Muthia Zadfa ${ }^{1}$ dan Irawan Sugoro $^{2}$ \\ ${ }^{1}$ Fakultas Sains dan Teknologi, Universitas Islam Negeri \\ Syarif Hidayatullah \\ Jl. Ir. H. Juanda No. 95, Tangerang Selatan, Banten, 15412 \\ ${ }^{2}$ Pusat Aplikasi Isotop dan Iradiasi, BATAN, \\ J1. Lebak Bulus Raya No.49, Jakarta 12440 \\ Email : meggapikoli@uinjkt.ac.id
}

\begin{abstract}
ABSTRAK
Gas metana dari ternak ruminansia merupakan salah satu penyumbang emisi gas rumah kaca terbesar di dunia, termasuk Indonesia. Gas metana yang bersumber dari peternakan berasal dari dua sumber emisi, yaitu pencernaan dan feses, sehingga produksinya dapat dikurangi melalui modifikasi pakan. Salah satu strategi untuk mengurangi produksi gas metana tersebut adalah dengan penambahan bakteri denitrifikasi, yang mengalihkan akseptor elektron untuk metanogenesis kepada denitrifikasi. Penelitian ini bertujuan untuk menyelidiki potensi penambahan bakteri denitrifikasi yang diinaktivasi dengan iiradiasi sinar Gamma dalam menurunkan produksi gas metana dalam cairan rumen sapi, yang diuji secara in vitro. Pada penelitian ini diuji empat perlakuan, yaitu dengan penambahan bakteri denitrifikasi aktif, bakteri denitrifikasi yang diinaktivasi dengan iradiasi Gamma Cell $1000 \mathrm{~Gy}$ dan bakteri denitrifikasi yang diinaktivasi menggunakan autoklaf 1,5 tekanan atmosfir, $120^{\circ} \mathrm{C}$ selama 15 menit, seluruhnya pada cairan rumen sapi yang diberi substrat hijauan sorgum secara in vitro. Hasil pengukuran dari masing-masing parameter berupa nilai $\mathrm{pH}$, amonia, volatile fatty acids total, asetat, propionat, butirat, biomassa bakteri, biomassa protozoa, produksi gas total dan produksi gas metana pada jam ke-24 dan 48 mendukung penurunan metanogenesis akibat penambahan bakteri denitrifikasi aktif dan inaktif. Pemberian bakteri denitrifikasi inaktif lebih besar menekan produksi gas metana dibandingkan dengan bakteri aktif. Penurunan produksi gas metana dari jam ke-24 sampai 48 dari perlakuan penambahan bakteri denitrifikasi inaktif-iradiasi, dan inaktif-autoklaf berturut-turut sebesar $41,5 \%$ dan $55,3 \%$, yang lebih tinggi daripada dari bakteri denitrifikasi aktif dengan penurunan sebesar 13,6\%.
\end{abstract}

Kata kunci : Bakteri denitrifikasi, gas metana, iradiasi, rumen, sapi

\begin{abstract}
Methane gas derived from ruminants is one contributor to greenhouse gas emissions in the world, including Indonesia. The methane gas emitted from livestock comes from two sources of emissions, i.e. digestion and faeces, so that production can be reduced through modification of the feed. One strategy for reducing methane gas production is by the addition of denitrifying bacteria, which transfer the electron acceptor for denitrification instead of methanogenesis. This study aims to investigate the potential of radiation-inactive denitrification bacteria in reducing production of methane gas in cow rumen liquid, which examined in vitro. In this study four treatments were examined which was consisted of the addition of active denitrifying bacteria, denitrifying bacteria inactivated by the irradiation Gamma Cell $1000 \mathrm{~Gy}$, and denitrifying bacteria inactivated by autoclaving 1.5 atmospheric pressure, $120^{\circ} \mathrm{C}$ for 15 minutes; all were applied to the cow rumen liquid with the forage sorghum as the substrate in vitro. Results on the measurement of some parameters which were $\mathrm{pH}$, ammonia, total volatile fatty acids, acetate, propionate, butyrate, bacterial biomass, protozoa biomass, production of total gas and methane gas at the 24 hour and 48 hour supported to a reduction of methanogenesis due to the addition of active and inactive denitrifying bacteria. The supplementation with the inactivated denitrifying bacteria reduced the methane gas production slightly higher than the active bacteria. The decrease in methane gas production from 24 to 48 hours from the addition of radiation-inactive and autoclaved-inactive denitrifying bacteria was $41.5 \%$ and $55.3 \%$, respectively, higher than that of the active denitrification bacteria with a decrease of $13,6 \%$.
\end{abstract}

Keywords : Cow, rumen, denitrifiying bacteria, methane gas, radiation 


\section{PENDAHULUAN}

Peternakan ruminansia merupakan penyebab emisi gas metana yang besar di Indonesia. Data tahun 2008 menunjukkan bahwa emisi gas metana dari sektor pertanian, termasuk peternakan, di Indonesia adalah $41,1 \%$ dari total emisi gas rumah kaca [1]. Metanogenesis yang terjadi di dalam sistem pencernaan rumen menghasilkan gas metana yang sebagian besar (80-95\%) diproduksi di dalam rumen dan sebagian lainnya (5-20\%) diproduksi di dalam usus besar. Gas tersebut dikeluarkan ke atmosfir melalui mulut [2]. Selain itu, emisi gas metana merugikan hewan itu sendiri. Hilangnya energi diet dalam bentuk metana bervariasi berdasarkan spesies hewan ruminan, yaitu berkisar 3,5-9\% [3].

Metanogenesis berlangsung dengan menggunakan $\mathrm{CO}_{2}$ sebagai akseptor elektron dalam kondisi anaerobik. Salah satu cara untuk menekan produksi gas metana adalah dengan memanfaatkan proses denitrifikasi, yang juga terjadi secara anaerobik. Pada denitrifikasi, senyawa nitrat $\left(\mathrm{NO}_{3}^{-}\right)$direduksi menjadi nitrit $\left(\mathrm{NO}_{2}{ }^{-}\right)$. Dengan adanya bakteri denitrifikasi, elektron dari reduktan akan diterima oleh $\mathrm{NO}_{3}{ }_{3}$, bukan oleh $\mathrm{CO}_{2}$, karena secara termodinamis denitrifikasi lebih menguntungkan daripada metanogenesis [4]. Cairan rumen kerbau yang diberi bakteri denitrifikasi inaktif-autoklaf menunjukkan pengurangan gas metana [5]. Oleh karena itu, bagaimana dampak adanya bakteri denitrifikasi terhadap metanogenesis dari cairan rumen sapi yang diuji secara in vitro menjadi masalah dari penelitian ini.

Penelitian yang dilakukan menguji perlakuan dengan bakteri denitrifikasi aktif dan inaktif. Bakteri aktif diduga lebih efektif dalam mengurangi gas metana karena aktif bermetabolisme. Namun perkembangan yang berlebih dikuatirkan berakibat terjadinya produksi asam yang berlebihan. Sementara itu, bakteri inaktif meskipun tidak dapat tumbuh, enzimenzimnya masih tersedia [6]. Metode inaktivasi yang digunakan adalah dengan iradiasi. Iradiasi gamma digunakan karena telah dikenal sebagai metode yang mengawetkan suatu bahan, termasuk organisme, tetapi tidak mengubah secara signifikan aktivitas enzim-enzimnya [7]. Sebagai pembanding, inaktivasi juga menggunakan autoklaf.

\section{BAHAN DAN METODE}

\section{Alat dan bahan}

Alat-alat utama yang digunakan adalah timbangan analitik, Gamma Cell, autoklaf, oven, grinder, desikator, tanur, hot plate, sentrifus, perangkat distilasi, syringe glass, gas analyzer, spektrofotometer, waterbath shaker, inkubator, mikroskop, cawan Conway, dan mikropipet. Bahan-bahan utama yang digunakan adalah isolat bakteri dentrifikasi dengan kode strain RS2, cairan rumen sapi Bali, sorgum, larutan rumen in vitro [8], larutan $\mathrm{K}_{2} \mathrm{CO}_{3}$, larutan methylgreen formalin salin, larutan $\mathrm{NaOH}$, indikator Conway, larutan $\mathrm{HCl}$, larutan $\mathrm{H}_{2} \mathrm{SO}_{4}$, nutrient agar, nutrient broth, indikator phenolphtalein $0,1 \%$, pewarna safranin, larutan Lowry I, aseton, vaselin, dan akuades.

\section{Persiapan substrat sorgum}

Potongan kecil hijauan sorgum dikeringkan dalam oven dengan suhu $600^{\circ} \mathrm{C}$ selama 48 jam, kemudian dihaluskan dengan menggunakan grinder. Sorgum disaring dengan menggunakan kain kasa sebanyak 4 lapis sehingga diperoleh serbuk yang halus.

\section{Produksi bakteri dentrifikasi}

Sebanyak $30 \quad \mathrm{ml}$ kultur bakteri diinokulasikan ke dalam nutrient broth dalam tabung reaksi, diberi gas $\mathrm{CO}_{2}$, dan diinkubasi selama 24 jam pada waterbath shaker. Kemudian kultur diinokulasikan ke dalam $500 \mathrm{ml}$ nutrient broth, diberikan gas $\mathrm{CO}_{2}$, dan diinkubasi selama 24 jam. Kultur inokulum tersebut dimasukkan ke dalam beberapa botol fial. Sebagai bakteri inaktif, kultur diinaktivasi dengan iradiasi dengan alat Gamma Cell $1000 \mathrm{~Gy}$, dan dengan autoklaf 1,5 atm, pada suhu $120^{\circ} \mathrm{C}$, selama 15 menit.

\section{Pembuatan larutan rumen in vitro}

Larutan untuk pengujian rumen in vitro terdiri dari larutan mikromineral, buffer, larutan, makromineral, dan resazurin [8]. Larutan mikromineral dibuat dengan mencampurkan 13,2 g $\mathrm{CaCl}_{2} \cdot 2 \mathrm{H}_{2} \mathrm{O}, 10 \mathrm{~g} \quad \mathrm{MnCl}_{2} \cdot 4 \mathrm{H}_{2} \mathrm{O}, 1 \mathrm{~g}$ $\mathrm{COCl}_{2} \cdot 6 \mathrm{H}_{2} \mathrm{O}, 8 \mathrm{~g} \mathrm{FeCl}_{3} \cdot 6 \mathrm{H}_{2} \mathrm{O}$, dalam $100 \mathrm{ml}$ akuades. Larutan buffer dibuat dari $35 \mathrm{~g} \mathrm{NaHCO}_{3}$ dan 4 g N $\mathrm{NH}_{4} \mathrm{HCO}_{3}$ dalam $1000 \mathrm{ml}$ akuades. Larutan makromineral dibuat dari 5,7 $\mathrm{g} \mathrm{Na}_{2} \mathrm{HPO}_{4}$, 6,2 $\mathrm{g} \mathrm{KH}_{2} \mathrm{PO}_{4}$, dan 0,6 g $\mathrm{MgSO}_{4} \cdot 7 \mathrm{H}_{2} \mathrm{O}$ dalam $1000 \mathrm{ml}$ akuades. Resazurin dibuat dari $100 \mathrm{mg}$ resazurin yang dilarutkan dalam $100 \mathrm{ml}$ akuades. 
Larutan pereduksi dibuat dari $373 \mathrm{mg} \mathrm{Na} 2 \mathrm{~S} . \mathrm{H}_{2} \mathrm{O}$, 2,6 $\mathrm{ml} \mathrm{NaOH} 1 \mathrm{~N}$ dan $62 \mathrm{ml}$ akuades.

\section{Persiapan cairan rumen sapi}

Cairan rumen diperoleh dari Rumah Potong Hewan Pasar Ciputat. Cairan rumen disaring menggunakan kain kasa empat lapis disertai pemberian gas $\mathrm{CO}_{2}$ [9].

\section{Uji in vitro}

Syringe glass yang berisi $0,4 \mathrm{~g}$ serbuk sorgum dan $100 \mu$ l bakteri denitrifikasi disiapkan, lalu ditambahkan $40 \mathrm{ml}$ cairan rumen dan larutan rumen in vitro. Proses pemasukan cairan rumen ke dalam syringe glass harus tidak menyisakan rongga kosong di dalamnya. Kultur dalam syringe glass tersebut diinkubasi dalam waterbath dengan suhu $39^{\circ} \mathrm{C}$. Macam perlakuan yang diuji dapat dilihat pada Tabel 1 .
Pengukuran produksi gas total dilakukan pada jam ke- $0,2,4,6,8,10,12,24$ dan 48 dengan cara membaca skala yang tertera pada syringe. Jika posisi piston telah melebihi $60 \mathrm{ml}$ maka nilai yang tertera pada skala syringe dicatat, kemudian posisi piston dikembalikan ke posisi $40 \mathrm{ml}$. Perhitungan produksi gas total mengacu pada prosedur evaluasi pakan [12]. Produksi gas $(\mathrm{ml} / 200 \mathrm{mg})=$ Produksi gas akhir - produksi gas awal - produksi gas kontrol. Pengukuran konsentrasi gas $\mathrm{CH}_{4}$ dan $\mathrm{CO}_{2}$ dilakukan menggunakan MRU gas Analyzer®. Pengukuran produksi gas memperlihatkan pengaruh penambahan bakteri dentirifikasi secara langsung pada konsentrasi gas yang terbentuk.

\section{Analisis data}

Data penelitian ini dianalisis dengan analisis variansi dua arah untuk mengetahui

Tabel 1. Perlakuan yang diuji

\begin{tabular}{|c|c|c|c|c|c|}
\hline \multirow{3}{*}{ Perlakuan } & \multicolumn{3}{|c|}{ Bakteri Denitrifikasi } & \multirow{3}{*}{ Sorgum $(\mathrm{g})$} & \multirow{3}{*}{$\begin{array}{c}\text { Cairan rumen + } \\
\text { Buffer }(\mathrm{ml})\end{array}$} \\
\hline & \multirow{2}{*}{ Aktif } & \multicolumn{2}{|c|}{ Inaktif } & & \\
\hline & & Iradiasi & Autoklaf & & \\
\hline A & $100 \mu \mathrm{l}$ & - & - & 0,4 & $40 \mathrm{ml}$ \\
\hline B & - & $100 \mu \mathrm{l}$ & - & 0,4 & $40 \mathrm{ml}$ \\
\hline $\mathrm{C}$ & - & - & $100 \mu \mathrm{l}$ & 0,4 & $40 \mathrm{ml}$ \\
\hline $\mathrm{D}$ & - & - & - & 0,4 & $40 \mathrm{ml}$ \\
\hline
\end{tabular}

Keterangan : A: Bakteri denitrifikasi aktif, B: Bakteri denitrifikasi inaktif-iradiasi, C: Bakteri denitrifikasi inaktif-autoklaf, D: Tanpa bakteri denitrifikasi

Pemeriksaan parameter-parameter berupa $\mathrm{pH}$, amonia $\left(\mathrm{NH}_{3}\right)$, volatile fatty acids (VFA) total, VFA parsial, jumlah bakteri dan protozoa, biomassa mikroorganisme, produksi gas total dan konsentrasi gas $\mathrm{CH}_{4}$ dan $\mathrm{CO}_{2}$, dilakukan setelah kultur diinkubasi selama 48 jam. Nilai pH cairan rumen merupakan salah satu indikator untuk mengetahui adanya pengaruh penambahan bakteri denitrifikasi terhadap komunitas mikroorganisme di dalam cairan rumen. Konsentrasi amonia ditentukan dengan teknik mikrodifusi [10]. Pengukuran konsentrasi amonia cairan rumen dilakukan untuk menggambarkan degradasi protein pakan dan denitrifikasi di dalam rumen. Pengukuran konsentrasi VFA total dan parsial menggunakan kromatografi gas (GC) bertujuan untuk mengetahui konsentrasi asetat, propionat dan butirat. Metode gravimetri digunakan untuk mengetahui biomassa bakteri dan protozoa [11]. perbedaan rata-rata masing-masing dari waktu, perlakuan, dan interaksi keduanya, terhadap masing-masing parameter, pada batas kepercayaan $95 \%$, setelah diketahui berdistribusi normal. Jika hasilnya berbeda nyata, uji Duncan digunakan untuk melihat jarak perbedaannya.

\section{HASIL DAN PEMBAHASAN}

\section{pH cairan rumen}

Gambar 1 menunjukkan nilai $\mathrm{pH}$ pada setiap perlakuan mengalami perubahan dengan pola yang serupa, yaitu pada jam ke-0 sampai 24 $\mathrm{pH}$ menurun, kemudian pada jam ke-24 hingga 48 meningkat. Setelah inkubasi 48 jam, nilai $\mathrm{pH}$ semua waktu dan perlakuan berkisar antara 7,017,07. Nilai $\mathrm{pH}$ tersebut berada dalam kisaran $\mathrm{pH}$ normal untuk aktivitas mikroorganisme rumen, 


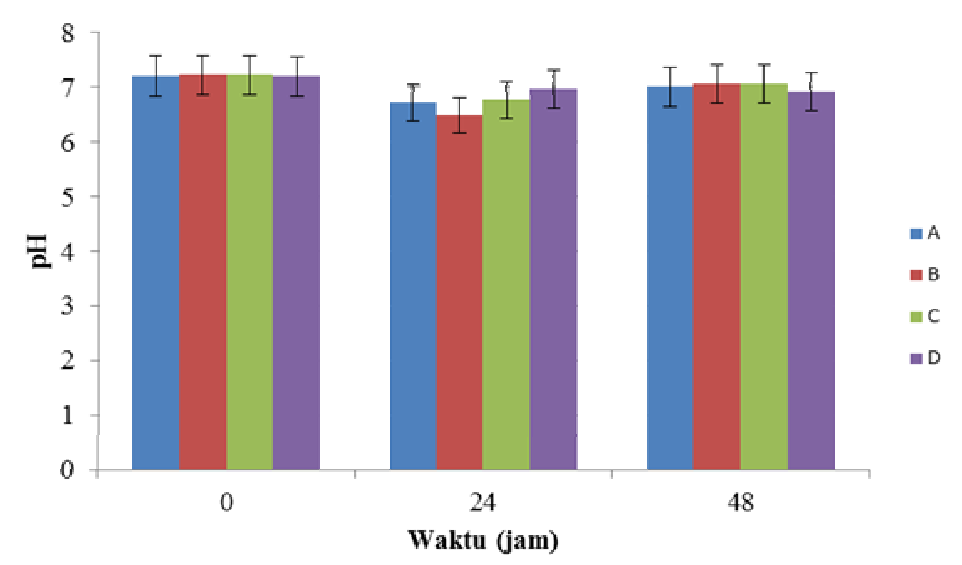

Gambar 1. Nilai pH cairan rumen sapi. A. Bakteri denitrifikasi aktif; B. Bakteri denitrifikasi inaktif-iradiasi; C. Bakteri denitrifikasi inaktif-autoklaf; D. Tanpa bakteri denitrifikasi

yaitu 5,5-7,0 [13]. Dengan demikian, penambahan bakteri denitrifikasi, baik aktif maupun inaktif, tidak mempengaruhi perubahan $\mathrm{pH}$.

\section{Konsentrasi amonia}

Hasil analisis variansi menunjukkan adanya perbedaan signifikan di antara konsentrasi amonia pada setiap perlakuan pada 0, 24 dan 48 jam. Hasil uji Duncan konsentrasi amonia pada interaksi waktu dan perlakuan menunjukkan nilai rata-rata amonia $(2,7 \mathrm{mM})$ tertinggi terjadi pada perlakuan bakteri denitrifikasi aktif dan inaktif-autoklaf pada jam ke- 0 , sedangkan terendah $(0,95 \mathrm{mM})$ pada perlakuan tanpa bakteri denitrifikasi pada jam ke48 (Gambar 2).
Sementara itu, pada jam ke-24 penambahan bakteri denitrifikasi inaktif-iradiasi menghasilkan konsentrasi amonia terendah. Hal ini menunjukkan terjadi aktivitas denitrifikasi yang rendah pada bakteri denitrifikasi inaktif-iradiasi. Perlakuan iradiasi diduga menyebabkan aktivitas enzim-enzim bakteri melemah. Iradiasi dapat menurunkan aktivitas enzim namun tidak menginaktifkan sama sekali, seperti yang pernah diteliti pada berbagai spesies mushroom yang diiradiasi [7]. Namun demikian, pada jam ke-48 konsentrasi amonia pada perlakuan bakteri denitrifikasi inaktif-iradiasi meningkat lebih tinggi daripada perlakuan tanpa penambahan bakteri denitrifikasi. Kultur tanpa penambahan bakteri

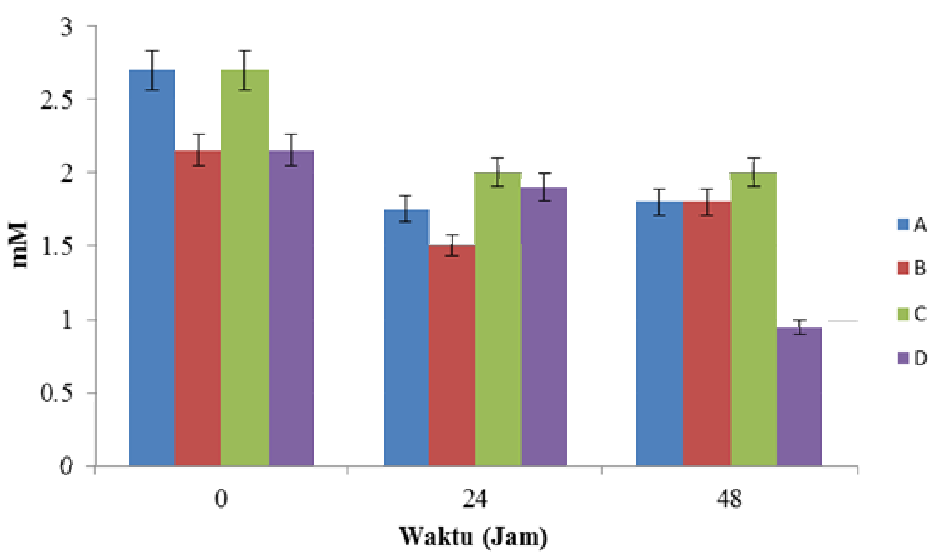

Gambar 2. Konsentrasi amonia cairan rumen sapi. A. Bakteri denitrifikasi aktif; B. Bakteri denitrifikasi inaktifiradiasi; C. Bakteri denitrifikasi inaktif-autoklaf; D. Tanpa bakteri denitrifikasi. 
denitrifikasi mengandalkan sebagian besar produksi amonia dari degradasi asam amino atau protein pakan. Oleh karena itu, meningkatnya konsentrasi amonia pada kultur dengan bakteri denitrifikasi inaktif-iradiasi menunjukkan denitrifikasi masih terjadi, dibandingkan dengan kultur tanpa penambahan bakteri denitrifikasi. Dugaan lainnya adalah amonia yang dihasilkan langsung diasimilasi menjadi protein baru, yang dimanifestasikan dalam bentuk peningkatan biomassa protozoa (Gambar 3); yang memerlukan pemeriksaan lebih lanjut. Selain itu, nitrit dapat dimetabolisme langsung menjadi produk akhir selain amonia, seperti gas-gas nitrogen dan nitrous-oxide, yang juga merupakan penyusun gas rumah kaca [14]. dihasilkan juga digunakan oleh mikroorganisme dalam rumen, termasuk metanogen. Konsentrasi VFA cairan rumen dari semua perlakuan dapat dilihat pada Tabel 2. Pada jam ke-24 dan 48, adanya penambahan bakteri denitrifikasi, baik aktif maupun inaktif, membuat konsentrasi asetat menjadi lebih rendah dibandingkan dengan perlakuan tanpa bakteri denitrifikasi. Sebagian besar metana dibentuk dari asetat, sehingga rendahnya konsentrasi asetat dapat menunjukkan bahwa produksi gas metana berhasil ditekan [16, 17].

Demikian pula pada konsentrasi propionat, adanya penambahan bakteri denitrifikasi, baik aktif maupun inaktif, membuat konsentrasi propionat menjadi lebih rendah dibandingkan
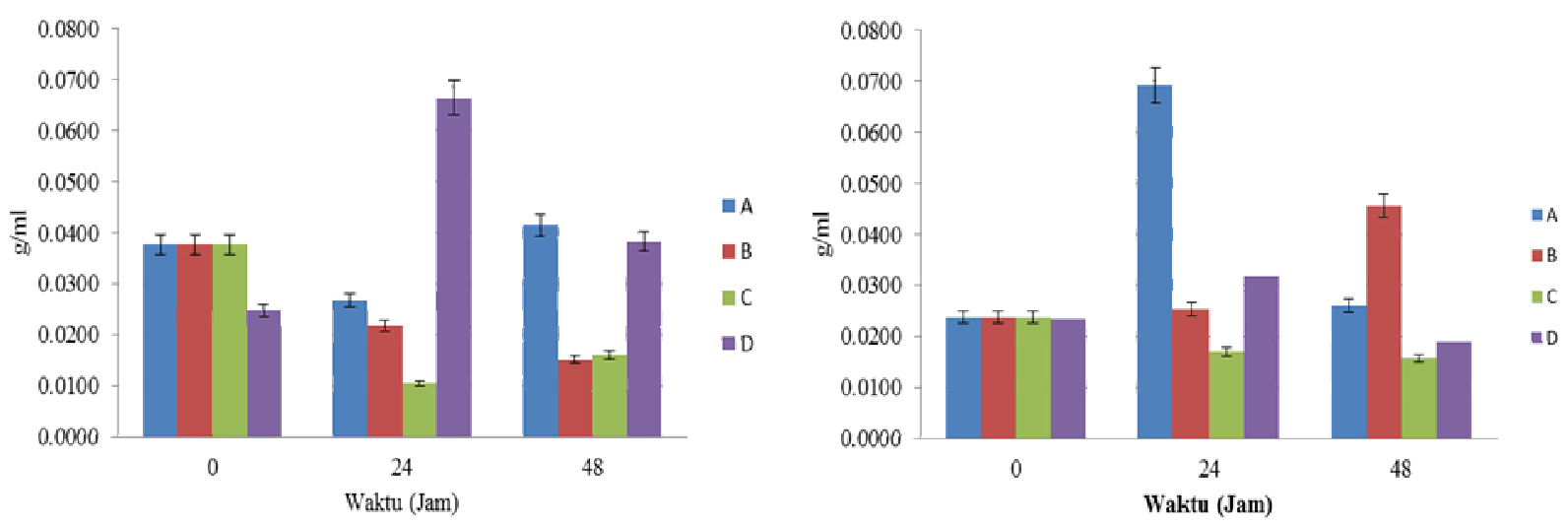

Gambar 3. Biomassa bakteri (gambar kiri) dan protozoa (gambar kanan) dalam cairan rumen sapi. A. Bakteri denitrifikasi aktif; B. Bakteri denitrifikasi inaktif-iradiasi; C. Bakteri denitrifikasi inaktif-autoklaf; D. Tanpa bakteri denitrifikasi

Dengan asumsi kecepatan degradasi pakan sama di antara semua perlakuan, perlakuan dengan bakteri denitrifikasi inaktif-autoklaf menghasilkan konsentrasi amonia tertinggi pada semua waktu pengamatan. Hal ini menunjukkan bahwa enzimenzim pada bakteri denitrifikasi yang mendapat perlakuan autoklaf berfungsi dengan baik. Hasil ini sesuai dengan penelitian lain yang menggunakan cairan ruman kerbau dengan kultur bakteri pereduksi nitrat yang diinaktivasi-autoklaf untuk mencegah akumulasi nitrit, sehingga mengurangi emisi gas metana [5].

\section{Konsentrasi Volatile Fatty Acids (VFA)}

VFA merupakan sumber energi utama bagi ternak ruminansia yang dihasilkan dari proses fermentasi pakan dalam rumen [15]. Energi yang dengan perlakuan tanpa bakteri denitrifikasi. Rendahnya propionat ini bersesuaian dengan konsentrasi asetat yang lebih rendah, karena propionat segera dikonversi menjadi asetat. Oksidasi propionat menjadi asetat, $\mathrm{CO}_{2}$ dan hidrogen dilakukan oleh kelompok bakteri pengoksidasi propionat yang tumbuh lambat [18], yang terdapat dalam cairan rumen sapi, seperti Syntrophobacter, Smithella, Pelotomacu-lum, dan Syntrophomonas [19]. Pertumbuhan mereka yang lambat mudah disaingi oleh bakteri denitrifikasi, sehingga akseptor elektron teralihkan pada denitrifikasi, dan secara tidak langsung menekan metanogenesis.

Sementara itu, konsentrasi butirat di antara semua perlakuan penambahan bakteri denitrifikasi tidak berbeda signifikan dibandingkan dengan 
Tabel 2. Konsentrasi VFA cairan rumen jam ke-0, 24 dan 48

\begin{tabular}{|c|c|c|c|c|}
\hline \multirow[t]{2}{*}{ Waktu } & \multicolumn{4}{|c|}{ Konsentrasi asetat (mmol/100ml) } \\
\hline & A & B & $\mathrm{C}$ & $\mathrm{D}$ \\
\hline 0 & 38,05 & 38,29 & 38,22 & 38,10 \\
\hline 24 & 36,08 & 34,08 & 35,91 & 48,05 \\
\hline \multirow[t]{3}{*}{48} & 35,29 & 36,88 & 42,05 & 72,05 \\
\hline & \multicolumn{4}{|c|}{ Konsentrasi propionat (mmol/100ml) } \\
\hline & A & B & $\mathrm{C}$ & $\mathrm{D}$ \\
\hline 0 & 29,05 & 29,54 & 29,12 & 29,51 \\
\hline 24 & 32,11 & 32,05 & 32,98 & 45,52 \\
\hline \multirow[t]{2}{*}{48} & 31,08 & 30,85 & 29,99 & 55,08 \\
\hline & \multicolumn{4}{|c|}{ Konsentrasi butirat (mmol/100ml) } \\
\hline & A & $\mathrm{B}$ & $\mathrm{C}$ & $\mathrm{D}$ \\
\hline 0 & 2,08 & 2,02 & 2,06 & 2,05 \\
\hline 24 & 1,82 & 1,86 & 1,87 & 1,82 \\
\hline \multirow[t]{2}{*}{48} & 2,03 & 2,21 & 2,05 & 1,99 \\
\hline & \multicolumn{4}{|c|}{ Asetat:propionat (mmol/100ml) } \\
\hline & A & $\mathrm{B}$ & $\mathrm{C}$ & $\mathrm{D}$ \\
\hline 0 & 1,30 & 1,29 & 1,31 & 1,29 \\
\hline 24 & 1,12 & 1,06 & 1,08 & 1,05 \\
\hline \multirow[t]{2}{*}{48} & 1,13 & 1,19 & 1,40 & 1,30 \\
\hline & \multicolumn{4}{|c|}{ Konsentrasi VFA total (mmol/100ml) } \\
\hline & $\mathrm{A}$ & $\mathrm{B}$ & $\mathrm{C}$ & $\mathrm{D}$ \\
\hline 0 & 69,18 & 69,05 & 69,10 & 69,12 \\
\hline 24 & 70,01 & 67,99 & 70,76 & 95,39 \\
\hline 48 & 68,4 & 69,94 & 74,09 & 129,12 \\
\hline
\end{tabular}

A. Bakteri denitrifikasi aktif; B. Bakteri denitrifikasi inaktif-iradiasi; C. Bakteri denitrifikasi inaktif-autoklaf; D. Tanpa bakteri denitrifikasi.

tanpa bakteri denitrifikasi, demikian pula antar waktu pengamatan. Hal ini menambah keyakinan bahwa bukan butirat, melainkan propionat, yang lebih banyak berperan dalam pembentukan asetat. Nilai rasio asetat:propionat pada semua perlakuan termasuk rendah, termasuk kontrol (perlakuan tanpa bakteri denitrifikasi). Hal ini disebabkan pakan yang digunakan adalah sorgum, yang merupakan pakan berserat tinggi. Rendahnya rasio asetat:propionat menguntungkan karena dapat menekan produksi metana. Hal ini bersesuaian dengan nilai $\mathrm{pH}$ yang menurun hanya sedikit dari nilai $\mathrm{pH}$ awal (Gambar 1). Sapi yang diberi pakan serat lebih banyak akan memiliki $\mathrm{pH}$ rumen yang menurun 0,3 unit dari $\mathrm{pH}$ awal, fermentasi serat terhambat, rasio asetat:propionat menurun, sehingga produksi metana menurun dua kali lipat [20].

Nilai rasio asetat:propionat terkecil pada jam ke-48 terjadi pada perlakuan dengan penambahan bakteri denitrifikasi aktif dan inaktifiradiasi. Hal ini menunjukkan penambahan bakteri denitrifikasi pada kedua perlakuan tersebut dapat menekan pembentukan gas metana lebih banyak daripada perlakuan-perlakuan lainnya. Hasil penelitian lain menunjukkan bahwa perbedaan produksi gas metana dipengaruhi oleh nilai rasio asetat:propionat, yaitu nilai rasio $\leq 1$ menghasilkan produksi gas metana dan dekomposisi VFA lebih lambat selama kurun waktu inkubasi daripada nilai rasio asetat:propionat $\geq 2$ [21]. Hal ini membuktikan bahwa bakteri denitrifikasi mampu mengalihkan akseptor elektron dari asam asetat ke proses denitrifikasi.

VFA sangat penting digunakan pertumbuhan mikroorganisme rumen yang membantu mencerna serat kasar dalam rumen, serta sebagai sumber kerangka karbon bagi pembentukan protein mikroorganisme. Nilai-nilai VFA parsial menunjukkan kisaran yang berbeda di antara perlakuan dan kontrol (Tabel 2). Produksi asetat pada perlakuan penambahan bakteri denitrifikasi aktif maupun inaktif lebih rendah daripada tanpa penambahan bakteri denitrifikasi. Rasio asetat:propionat:butirat pada perlakuan bakteri denitrifikasi aktif (52:45:4) dan inaktif-iradiasi (53:44:4) yang dibandingkan dengan tanpa bakteri denitrifikasi (56:43:4) 
menunjukkan penurunan proporsi asetat dan peningkatan propionat. Penghambatan asetat oleh peningkatan propionat dapat menjadi indikasi produksi gas metana yang lebih rendah [17]. Sementara itu, konsentrasi VFA total yang berkisar antara 67,99-74,09 $\mathrm{mmol} / 100 \mathrm{ml}$ dari perlakuan-perlakuan dengan penambahan bakteri denitrifikasi masih berada pada kisaran optimal untuk pertumbuhan mikroorganisme dalam cairan rumen, yaitu 70-150 mmol/100ml [22].

\section{Biomassa Bakteri dan Protozoa}

Biomassa merupakan hasil dari pertumbuhan mikroorganisme cairan rumen, yaitu bakteri dan protozoa, serta sebagian kecil fungi, yang memanfaatkan sumber nitrogen dan sumber karbon. Gambar 3 menunjukkan biomassa bakteri dan biomassa protozoa pada setiap perlakuan pada jam ke-0, 24 dan 48.

Hasil analisis variansi menunjukkan adanya perbedaan nyata $(p<0,05)$ untuk masing-masing waktu, perlakuan, dan interaksi di antara keduanya. Hasil uji Duncan pada interaksi waktu dan perlakuan menunjukkan nilai rata-rata biomassa bakteri tertinggi $(0,0667 \mathrm{~g} / \mathrm{ml})$ adalah pada perlakuan tanpa bakteri denitrifikasi pada jam ke-24, sedangkan terendah $(0,0106 \mathrm{~g} / \mathrm{ml})$ pada perlakuan bakteri denitrifikasi inaktif-autoklaf pada jam ke-24, yang semuanya berbeda secara signifikan. Nilai-nilai biomassa bakteri tersebut hampir seluruhnya bersesuaian dengan biomassa protozoa, yaitu ketika biomassa bakteri rendah maka biomassa protozoa akan meningkat. Hal tersebut karena protozoa merupakan predator bakteri, yang mencernanya sebagai sumber asam amino bagi pertumbuhannya [23].

Selain itu, penurunan biomassa bakteri pada jam ke-0 sampai 24 pada perlakuan dengan bakteri denitrifikasi berkaitan dengan konsentrasi amonia yang juga menurun (Gambar 2). Hal ini menunjukkan bahwa aktivitas bakteri denitrifikasi diduga dipengaruhi oleh persaingan dengan mikroorganisme lain sehingga aktivitas denitrifikasi dalam cairan rumen menurun, yang ditandai dengan penurunan konsentrasi amonia. Dalam proses denitrifikasi, amonia dihasilkan dari reduksi nitrit. Reduksi nitrit berlangsung lebih lambat dibandingkan dengan reduksi nitrat menjadi nitrit, yang dapat menyebabkan akumulasi nitrit, sehingga konsentrasi amonia yang rendah menggambarkan proses denitrifikasi yang rendah (14).
Biomassa protozoa rumen juga berkaitan dengan konsentrasi VFA total. Produksi VFA total yang rendah mengurangi pasokan sumber energi bagi protozoa. Secara tidak langsung, protozoa berperan dalam produksi metana, yaitu menyediakan habitat bagi bakteri metanogen. Protozoa juga berperan dalam transfer hidrogen pada proses metanogenesis [24]. Selain itu, protozoa sebagai predator diperlukan sebagai pengendali komunitas mikroorganisme di dalam rumen. Eliminasi protozoa ciliata meningkatkan suplai protein (dari mencerna protein bakteri) hingga $30 \%$, dan mengurangi produksi metana hingga $11 \%$ [25].

Terkait dengan penggunaan bakteri denitrifikasi, biomassa bakteri yang terendah pada jam ke-48 pada perlakuan penambahan bakteri denitrifikasi inaktif-iradiasi diduga disebabkan oleh predasi yang tinggi oleh protozoa, yang ditandai dengan biomassa protozoa yang tertinggi (Gambar 3). Oleh karena itu, diperlukan upaya lain untuk mencapai keseimbangan komunitas protozoa yang mencapai penurunan produksi metana, misalnya dengan tidak memangsa bakteri denitrifikasi seluruhnya, tetapi tetap tidak mengganggu proses pencernaan di dalam rumen.

\section{Produksi Gas}

Konsentrasi gas total dan metana pada semua perlakuan setelah inkubasi selama 0,24 , dan 48 jam dapat dilihat pada Gambar 4. Volume gas yang terukur dari semua perlakuan menunjukkan bahwa terdapat aktivitas mikroorganisme anaerobik dan metanogenik penghasil gas. Komposisi biogas meliputi metana, nitrogen, karbondioksida, nitrous oxide, dan sebagainya [4].

Secara umum pada semua perlakuan volume gas total mengalami peningkatan dari jam ke-24 hingga 48. Namun demikian, terdapat perbedaan pada peningkatan di antara perlakuanperlakuan. Perlakuan dengan penambahan bakteri denitrifikasi aktif meningkatkan volume gas total sebesar 3,2\% dari volume gas awal (jam ke-24), sedangkan penambahan bakteri denitrifikasi inaktif-iiradiasi dan inaktif-autoklaf hampir serupa, yaitu masing-masing $21,4 \%$ dan $21,1 \%$. Sementara itu, tanpa penambahan bakteri denitrifikasi volume gas total meningkat sangat besar, yaitu 47,4\%. Hasil ini menunjukkan bahwa penambahan bakteri denitrifikasi, baik aktif maupun inaktif, telah menekan produksi gas secara keseluruhan. 

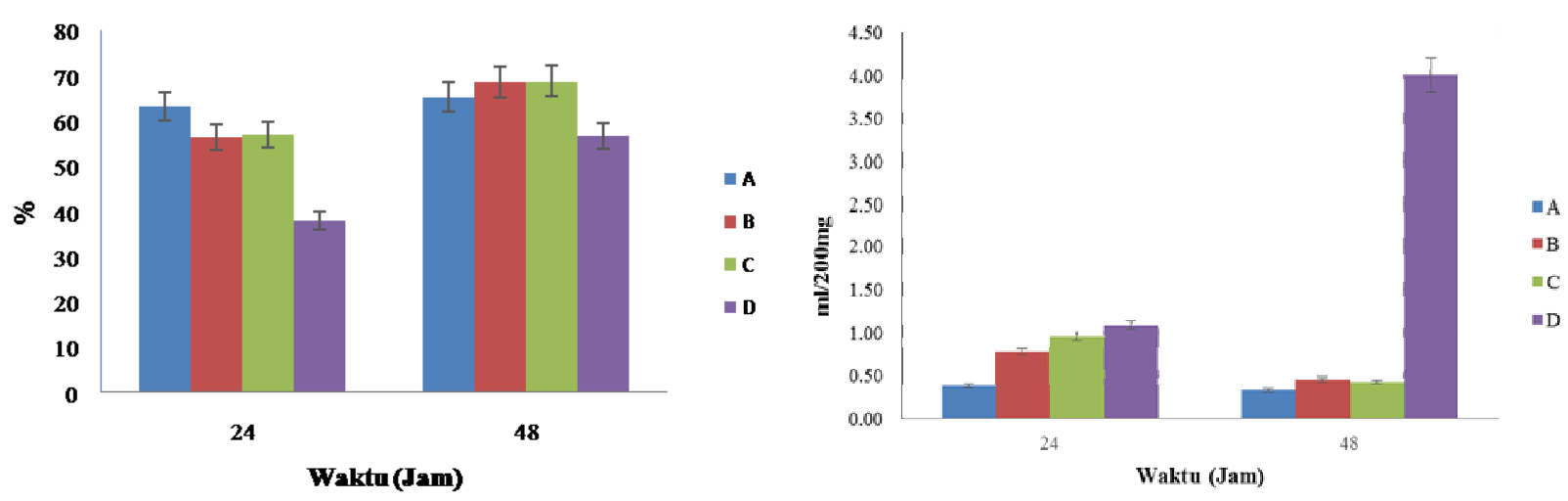

Gambar 4. Produksi gas total (kiri) dan metana (kanan) dalam cairan rumen sapi. A. Bakteri denitrifikasi aktif; B. Bakteri denitrifikasi inaktif-iradiasi; C. Bakteri denitrifikasi inaktif-autoklaf; D. Tanpa bakteri denitrifikasi

Sejalan dengan hasil tersebut, hasil analisis variansi menunjukkan adanya perbedaan nyata $(p<0,05)$ untuk masing-masing waktu, perlakuan, dan interaksi di antara keduanya pada konsentrasi metana yang terbentuk. Hasil uji Duncan pada interaksi waktu dan perlakuan menunjukkan nilai rata-rata tertinggi $(4,02 \mathrm{ml} / 200 \mathrm{mg})$ pada perlakuan tanpa bakteri denitrifikasi pada jam ke48, yang berbeda secara signifikan. Hal ini menunjukkan bahwa perlakuan penambahan bakteri denitrifikasi dapat menekan produksi gas metana dibandingkan perlakuan tanpa penambahan bakteri denitrifikasi. Perbedaan tersebut didukung pula oleh penurunan produksi metana dari jam ke-24 sampai 48, yaitu perlakuan penambahan bakteri denitrifikasi aktif, inaktifiradiasi, dan inaktif-autoklaf berturut-turut sebesar $13,6 \%, 41,5 \%$, dan 55,3\%. Sementara itu, produksi metana pada perlakuan tanpa penambahan bakteri denitrifikasi pada jam ke-48 malah meningkat sebesar $267 \%$ dibandingkan pada jam ke-24. Hal ini sesuai dengan hasil penelitian lain yang menunjukkan bahwa denitrifikasi menghambat metanogenesis, yaitu jumlah gas metana yang dihasilkan berbanding terbalik dengan jumlah senyawa-senyawa $\mathrm{NO}_{\mathrm{x}}{ }^{-}$ yang ditambahkan karena mereka merupakan akseptor elektron yang lebih disukai [14].

Hasil dari produksi gas total dan gas metana tersebut menunjukkan bahwa bakteri denitrifikasi aktif paling kecil meningkatkan produksi gas total, sehingga dapat dikatakan paling besar menekan produksi gas total, namun paling sedikit menekan produksi gas metana. Sementara itu, bakteri denitrifikasi-inaktif, baik inaktif-iradiasi maupun inaktif autoklaf paling besar menekan produksi metana, meskipun peningkatan produksi gas total lebih besar daripada yang diperoleh dari bakteri denitrifikasi aktif. Hasil penelitian Smith \& Parson (1985) menunjukkan bahwa aktivitas enzim denitrifikasi tidak tergantung pada aktivitas sel karena pada tanah yang dikeringkan selama 7 hari, kehilangan aktivitas enzim-enzim ini hanya 16-29\% dari aktivitas awal enzim pada tanah segar [26].

Bakteri denitrifikasi aktif mampu melakukan metabolisme dan berkembang dalam jumlah yang banyak dan menghasilkan enzim yang lebih banyak pula dibandingkan dengan inaktif; namun jika jumlahnya berlebihan akan menyebabkan asidosis. Aktivitas enzim denitrifikasi tidak berhubungan dengan jumlah pelaku denitrifikasi atau kecepatan denitrifikasi; aktivasi enzim-enzim denitrifikasi lebih penting daripada kecepatan pertumbuhan pelaku denitrifikasi atau kecepatan sintesis enzim-enzim tersebut [26]. Kemudian denitrifikasi mengalihkan akseptor elektron dari metanogenesis ke dalam proses denitrifikasi [27]. Produksi akhir metana berbanding terbalik dengan jumlah senyawasenyawa $\mathrm{NO}_{\mathrm{x}}^{-}$awal, sehingga mengindikasikan bahwa mereka merupakan akseptor elektron yang lebih disukai daripada metanogenesis [28]. Hasil penelitian ini membuktikan bahwa penggunaan bakteri denitrifikasi inaktif dapat menekan produksi metana lebih baik daripada bakteri denitrifikasi aktif, sehingga dapat dijadikan inokulum dalam pakan ternak. Selain itu, penambahan bakteri denitrifikasi hendaknya disertai penambahan senyawa nitrat untuk meningkatkan kecepatan denitrifikasi. 


\section{KESIMPULAN}

Penambahan bakteri denitrifikasi ke dalam pakan dapat menekan produksi metana dan asamasam lemak prekursornya di dalam cairan rumen sapi, dibandingkan dengan tanpa penambahan bakteri denitrifikasi. Bakteri denitrifikasi inaktif, baik inaktif-iradiasi maupun inaktif autoklaf, lebih efektif dalam mengurangi produksi metana dibandingkan dengan bakteri denitrifikasi aktif setelah diinkubasi 24 dan 48 jam.

\section{UCAPAN TERIMA KASIH}

Penulis mengucapkan terima kasih kepada kepada PAIR BATAN yang telah membantu penelitian ini melalui fasilitas dan dana riset dari DIPA.

\section{DAFTAR PUSTAKA}

1. The World Bank. Agricultural methane emissions (\% of total) [Internet]. 2012. Available from: http://data.worldbank.org/indicator/EN. ATM.METH.AG.ZS

2. Martin C, Rouel J, Jouany JP, Doreau M, Chilliard Y. Methane output and diet digestibility in response to feeding dairy cows crude linseed, extruded linseed, or linseed oil. J. Anim Sci. vol. 86, no. 10, pp. 2642-50, 2008.

3. Hook SE, Wright ADG, McBride BW. Methanogens: Methane producers of the rumen and mitigation strategies. Archaea, pp. 50-60, 2010.

4. Fang HHP, Zhou G-M. Interactions of Methanogens and Denitrifiers in Degradation of Phenols. J. Environ Eng., vol. 125, no. 1, pp. 57-63, 1999.

5. Sakthivel PC, Kamra DN, Agarwal N, Chaudhary LC. Effect of sodium nitrate and nitrate reducing bacteria on in vitro methane production and fermentation with buffalo rumen liquor. AsianAustralasian J. Anim Sci., vol. 25, no. 6, pp. 812-7, 2012.
6. Cottle DJ, Nolan J V., Wiedemann SG. Ruminant enteric methane mitigation: A review. Anim Prod Sci., vol. 51, no. 6, pp. 491-514, 2011.

7. Fernandes $\hat{A}$, Antonio AL, Oliveira MBPP, Martins A, Ferreira ICFR. Effect of gamma and electron beam irradiation on the physico-chemical and nutritional properties of mushrooms: A review. Food Chem., vol. 135, no. 2, pp. 641-50, 2012.

8. Goering HK, Van Soest PJ. Forage fiber analysis. Agric Handb., (379), pp. 1-19, 1970.

9. Preston TR. Tropical animal feeding [Internet]. Food and Agriculture Organization of the United Nations Rome. 1995. Available from: http://www.fao.org/DOCREP/003/V932 7E/V9327E00.HTM

10. Conway EJ. Micro-diffusion analysis and volumetric error. Crosby Lockwood \& Son, Ltd., London, England. pp. 306, 1947.

11. Blümmel $M$, Steinga $\beta$ H, Becker K. The relationship between in vitro gas production, in vitro microbial biomass yield and $\mathrm{N}$ incorporation and its implications for the prediction of voluntary feed intake of roughages. $\mathrm{Br} J$. Nutr. vol. 77, no. 6, pp. 911-21, 1997.

12. Krishnamoorthy U. RCA regional training workshop on in vitro techniques for feed evaluation. The international Atomic Energy Agency Vienna, Austria and Department of Livestock Production Management, Veterinary College University of Agricultural Science. Bangalore. India, 2001.

13. Castillo-González AR, Burrola-Barraza ME, Domínguez-Viveros J, Chávez-Martínez A. Rumen microorganisms and fermentation. Arch Med Vet. vol. 46, no. 3, pp. 349-61, 2014. 
14. Yang C, Rooke JA, Cabeza I, Wallace RJ. Nitrate and inhibition of ruminal methanogenesis: Microbial ecology, obstacles, and opportunities for lowering methane emissions from ruminant livestock. Front Microbiol. vol. 7, pp. 114, 2016.

15. Orskov, Egil Robert; Ryle M. Energy nutrition in ruminants. London: Elsevier Applied Science, pp. 149, 1990.

16. Ferry JG. Methanogenesis: ecology, physiology, biochemistry \& genetics. Springer Science \& Business Media, 2012.

17. Na, Renhua, Hongming Dong, Zhiping Zhu, Yongxing Chen HX. Effects of Forage Type and Dietary Concentrate to Forage Ratio on Methane Emissions and Rumen Fermentation Characteristics of Dairy Cows in China. Agric Biosyst Eng Publ. vol. 56, pp. 1115-22, 2013.

18. Li C, Moertelmaier C, Winter J, Gallert C. Microbial community shifts during biogas production from biowaste and/or propionate. Bioengineering. vol. 2, no. 1, pp. 35-53, 2015.

19. Mathai PP, Zitomer DH, Maki JS. Quantitative detection of syntrophic fatty acid-degrading bacterial communities in methanogenic environments. Microbiology. vol. 161, no. 6, pp. 1189-97, 2015.

20. Russell JB. The Importance of $\mathrm{pH}$ in the Regulation of Ruminal Acetate to Propionate Ratio and Methane Production In Vitro. J. Dairy Sci. vol. 81, no. 12, pp. 3222-30, 1998.
21. Wagner AO, Reitschuler C, Illmer P. Effect of different acetate: Propionate ratios on the methanogenic community during thermophilic anaerobic digestion in batch experiments. Biochem Eng. J., vol. 90, pp. 154-61, 2014.

22. McDonald P, Edwards R, Greenhalgh JFD, Morgan C, Sinclair L, Wilkinson RG. Animal nutrition. 7th ed. Pearson, pp. 365, 2011.

23. Soetanto H. Gizi Ternak Ruminansia Sesuai Stadia Fisiologisnya. Jurusan Nutrisi dan Makanan Ternak. Fakultas Peternakan Universitas Brawijaya. Malang, pp. 119, 2002.

24. Machmüller A, Soliva CR, Kreuzer M. Effect of coconut oil and defaunation treatment on methanogenesis in sheep. Reprod Nutr Dev. vol. 43, pp. 41-55, 2003.

25. Newbold CJ, De la Fuente G, Belanche A, Ramos-Morales E, McEwan NR. The role of ciliate protozoa in the rumen. Front Microbiol. vol. 6, pp. 1-14, 2015.

26. Smith MS, Parsons LL. Persistence of denitrifying enzyme-activity in dried soils. Appl Environ Microbiol. vol. 49, no. 2, pp. 316-20, 1985.

27. Wei T. the Biological Metabolism of Nitrate and Nitrite in. Thesis. Sam Houston State University, Texas, 2004.

28. Banihani Q, Sierra-Alvarez R, Field JA. Nitrate and nitrite inhibition of methanogenesis during denitrification in granular biofilms and digested domestic sludges. Biodegradation. vol. 20, no. 6, pp. 801-12, 2009. 